Instructions for authors, subscriptions and further details:

\title{
http://rimcis.hipatiapress.com
}

\section{Malaysian Sandwich Generation Issues and Challenges in Elderly Parents Care}

Shaista Noor ${ }^{1}$, Filzah Md Isa ${ }^{1}$

1) Taylors University, Lakeside Campus, Malaysia

Date of publication: article first published online October 22, 2020; Issue published November 30, 2020

Edition period: November 2020 - March2021

To cite this article: Noor, S., Md Isa, F. (2020). Malaysian Sandwich Generation Issues and Challenges in Elderly Parents Care. International and Multidisciplinary Journal of Social Sciences, 9(3), 289-312.

doi:10.17583/rimcis.2020.5277

To link this article: http://doi.org/10.17583/rimcis.2020.5277

\section{PLEASE SCROLL DOWN FOR ARTICLE}

The terms and conditions of use are related to the Open Journal System and to Creative Commons Attribution License(CC-BY). 
Sciences Vol. 9 No. 3 November 2020 pp. 289-312

\section{Malaysian Sandwich Generation Issues and Challenges in Elderly Parents Care}

Shaista Noor

Taylors University
Filzah Md Isa

Taylors University

\section{Abstract}

Ageing is a growing concern all around the world and also one of the biggest challenges for developing and developed countries. Malaysia is a country where ageing care centres are actively running under the government, NGOs, the public sector, and recently a few of the religious centres and entrepreneurs are working in this regard. The facilities in ageing care centres are not up to the mark due to which sandwich generation families are still providing support to their elderly parents in Malaysia. Hence, this paper aims to highlight the concept of sandwich generation focuses on the new inclinations in a familial responsibility in the form of support and cares for elderly parents along with children. This paper discusses the issues and challenges confronted by the sandwich generation residing in the leading states of Malaysia. This study adopts the qualitative research strategy semi-structured interview technique has used for data collection. The sample size consists of five (5) sandwich generation families living in leading states of Malaysia (Johor, Penang, Kedah, Selangor, and Klang Valley area). The results reveal that financial, emotional, dim future, stress, fewer savings, and time management are the main issues confronting sandwich generation in Malaysia. A recommendation plan is being produced based on the problems facing by the sandwich generation.

Keywords: sandwich generation, issue and challenges, ageing elderly, Malaysia. 
Sciences Vol. 9 No. 3November 2020 pp. 289-312

\section{Problemas y desafíos de la generación sandwich de Malasia en el cuidado de padres ancianos}

Shaista Noor

Taylors University
Filzah Md Isa

Taylors University

\section{Resumen}

El envejecimiento es una preocupación creciente en todo el mundo, y uno de los mayores retos para los países desarrollados o en vías de desarrollo. Malasia es un país en el que los centros de cura y cuidado de los ancianos están bajo la dirección del gobierno, de las ONG, del sector público, y recientemente también hay centros religiosos y empresarios trabajando en este ámbito. Las instalaciones en los centros de atención para personas mayores no están a la altura, por ello las familias de la generación sándwich todavía brindan apoyo a sus padres ancianos en Malasia. Este artículo pretende resaltar el concepto de Generación Sándwich centrándose en las nuevas inclinaciones hacia la responsabilidad familiar en forma de apoyo y cuidado a los padres ancianos junto con los hijos. El artículo debate los problemas y oportunidades que afronta la generación sándwich que reside en los estados más desarrollados de Malasia. Este estudio adopta una estrategia de investigación cualitativa y para la recolección de datos se ha usado la técnica de entrevistas semiestructuradas. El tamaño muestral consiste en cinco familias de la Generación Sándwich que viven en algunos de los principales estados de Malasia (Johor, Penang, Kedah, Selangor, y en el área del valle de Klang). Los resultados revelan que los principales problemas que enfrenta esta generación en Malasia son los problemas financieros, emocionales, el futuro oscuro, el estrés, la reducción de los ahorros y la gestión del tiempo. Se está elaborando un plan de recomendaciones basado en ellos.

Palabras clave: generación sándwich, problemas y desafíos, envejecimiento de los ancianos, Malasia 
sia is experiencing demographic change due to the transitioning of a larger span of people into an old age cohort, resulting in an increasingly ageing population. This demographic transformation influences society and its socio-cultural norms. It has also affected the families residing in Asian countries including Malaysia, as the joint family setup is a common practice in almost all Asian countries (Selvaratnam et al., 2010), where aged parent care is considered mandatory along with the responsibility of children. On a different note, western culture is also prevailing in Malaysian society in the form of living of elderly parents with a spouse or alone. Still, in most situations, it is quite typical to find families living together with their extended families in Malaysia (Uitdehaag, 2019; Phua et al., 2019), especially their elderly parents. The term "Sandwich Generation" is commonly used in the USA over the year 1981 (Tebes et al., 2000; Sinha, 2013) defined as the middle age person around 30-45 years, living with aged parents and children (Hammer et al., 2008) and responsible for taking care of children and elderly parents simultaneously.

The "Sandwich Generation" divides their resources among the children and aged parents (Broady, 2019). Turgeman et al. (2020) explain that the sandwich generation pressed between children demands and caregiving responsibility of old parents. Simultaneously, they have to face the workfamily conflict when familial responsibilities and pressure collide with work and demands (Maon et al., 2016). The work-family conflicts always arise in the low-income group and affect the caregiver's life in terms of job and family life satisfaction (Ahmad et al., 2016). Hence, Malaysian's sandwich generation is fulfilling the dual responsibility in the form of children support and care of aged parents. They are reluctant to withdraw from their filial obligation to the parents even though sometimes the elderly care is becoming a challenge for them due to various old age chronic diseases, especially dementia that usually come with old age.The dementia is an acquired brain disease characterised by the progressive deterioration of cognitive functions and functional impairment, which affects the whole family's daily activities (Turgeman et al., 2020), due to sudden profound weakness, drowsiness and bed-bounding of elderly. The sandwich generation caregiver in Asian countries feels their responsibility to care the elderly family member as a measure of respect and expected duty of a son or daughter (Kling, 1995; Ahmad et al.,2016). Relating to this, Phua et al. (2019) stated that Asians have 
stronger feelings of guilt than the Americans. Therefore, Asian people are always striving hard to do their best for the families' wellbeing including Malaysians, regardless of ethnicity i.e. Malay, Chinese, Indians and others (Ahmad et al., 2016).

At present, the sandwich generation in Malaysia is playing a remarkable role in elderly care, although they are facing challenging situations. For instance, the Malays who are mostly Muslim and adhered to the Islamic teachings and values, are very concerned about caring for their ageing parents as it stresses in the religion (Phua et al., 2019). Previous literature shows other various challenges such as finances, health issues children care, time constraints that are disturbing both women and men of sandwich generation (Chassin, Macy, Seo, Presson \& Sherman, 2010; Papastavrou, Charalambous, Tsangari \& Karayiannis, 2012; Maon et al., 2016; ZehnerQurada et al., 2014; Ahmad et al., 2016). In line with this, Hammer and Neal (2008) view the sandwich generation from a broader perspective, regarding a propensity of mental health issues (Solberg et al., 2014; Zucchella et al., 2012) which is due to familial consequences of taking care of children younger than 18 years along with aged parents (Tajvar et al., 2008). These responsibilities demand most of their times, finance, and efforts (Turgeman et al., 2020).

The present study is an attempt to highlight the main issues confronted by the sandwich generation as they often experience a feeling of depression, trouble in managing the task, relationships and time for themselves. Thus, there is a dire need for the formulation of strategies for the well-being of sandwich generation. Undoubtedly, it is a big challenge for Malaysia to manage an ageing society, as until the year 2028, Malaysia will be in the list of ageing population countries like many developed countries. More importantly, the findings of this study can help the government to overcome some extent of the ageing tsunami in Malaysia in several ways, either directly or indirectly. Below mentioned the research objective and question.

\section{Research Objective and Question}

RO: To explore the issues and challenges faced by women caregivers in the Sandwich generation family in Malaysia? 
RQ: What are the main issues and challenges faced by women caregivers in the Sandwich generation family in Malaysia?

\section{Literature Review}

The increase in life expectancy of baby boomers (1946-1964) and less fertility of many married couples are becoming the main reason for the ageing population, which ultimately results in the lack of younger generation for elderly care. Hence, the sandwich generation is experiencing the dual responsibility of children along aged parents care, and are usually facing work-family conflicts and other risks. Burdanised too many responsibilities may be harmful to their physical and emotional health, work-life, and family life balance, and health conditions (ZehnerQurada et al., 2014).

Past researches highlight that sandwich generation caregivers work life is affected due to hectic and dual responsibility of elderly parents and children care (Pierret, 2006; Hammer et al., 2008; Tajvar, 2008; Ahmad et al., 2016). Researches also point out that many sandwich generation married women are doing multiple jobs such as managing the home and workplace, along with caring for their elderly parents (Rubin et al., 2009; Pines et al., 2011; Sinha, 2013; Ahmad et al., 2016). In this regard, sandwich generation women are providing more financial help in fulfilling household demands and children schooling, as compared to spending on their parents or in-laws. Supposedly the fulfilment of older parents' needs should mostly come on the shoulder of sandwich generation men as compared to women (Igarashi et al., 2013). However, almost $75 \%$ responsibility of elderly parents' cares at home is on the women's shoulders. It could lead the women to come across more mental health issues as compared to men (Magaña et al., 2007; Zucchella et al., 2012).

Most societies especially Asians, prefer women to be involved in the care of parents, children, and as well as the sick member of the family (Papastavrou, Charalambous, Tsangari \& Karayiannis, 2012). In many cases, the women's health and wellbeing are not given a priority by their spouse, siblings and close relatives. In Malaysia for example, among many sandwich generation families, women too are burdened with individual illness, along with household, children care, and job responsibilities at the workplace 
(Seoud et al., 2015). So they have more chances of falling ill or exposing themselves to mental illness due to their hectic routine lifestyles. Their multiple responsibilities also lead them to experience work-life conflict, as Pines et al. (2011) stated that elderly and children care responsibilities becoming more demanding with time, resulting in lesser time and energy left for a job at the workplace. Thus, this situation triggers the Work-Family Conflict (WFC) and Family-Work-Conflict (FWC) in the sandwich generation's individual life. These conflicts can emerge individually or sometimes together depending on the circumstances. For instance, WorkFamily Conflict arises when the pressure and the demand of the work and family pressure and demand mandate at the same time, and Family-Work Conflict happens when the family demand and influence bump with work demand also at the same time (Pines et al., 2011; Solberg \& Peterson, 2014; Turgeman et al., 2020).

Previous research implicates married sandwich generation suffer from a higher level of depression, which is almost $22 \%$ to $36 \%$ scoring above the depression cut off score (Turgeman et al., 2020). Besides, sandwich generation also experiences a higher level of work-family conflicts and high absenteeism from work (Ahmad et al., 2016; Chassin et al., 2010; Hammer et al., 2008; Robinson et al., 2003). Therefore, this study attempts to discuss the issues and challenges of Malaysian Sandwich Generation in elderly parents' care. The literature also lacks the problems of sandwich generation caregivers.

\section{Methodology}

The methodology adopted plays an influential role in getting the answer to the research question and objective. The qualitative research strategy has used for the present study. For this purpose, ten sandwich generation families selected throughout Malaysia. The snowball-sampling technique is used by asking the people if they know any sandwich generation family willing for the interview (Patton, 2002). The criteria to choose the sandwich generation family was as follows:

1. The Sandwich Generation women must be a mother.

2. The Sandwich Generation mothers have at least one child with less than 18 years of age and look after their mother.

3. Remaining children also dependent on her. 
4. Providing care to at least one Parent/ in-laws.

5. The Parent/in-laws are or used to be sharing the same home in which sandwich generation family residing.

For this Qualitative Research strategy, a detailed telephonic interview strategy has used. The qualitative data provides the layout of the situation that drags the reader into the actual time and place of the observation. Thus, someone else experience summed up in qualitative research in the form of the story of one's practical skills (Patton, 2002; Hall, 2016). The interviews conducted in English during the month of April-May, 2019. The duration lasted about 25-30 minutes. The selection of the number of participants for this study based on Creswell's (2006) suggestion that is between 5-25 respondents, which are considered enough for a phenomenological study. The interview protocol revolved around these questions:

1. How do you feel about your caregiving role and a mother role?

2. Does your husband help you in a caregiving role?

4. How do you think about your family life because of the caregiving role?

5 . Which type of challenges did you come across in your caregiving role?

6 . What do you foresee for your future and your role as a sandwich generation caregiver?

The saturation point has achieved due to which the interviews limited to five participants from Johor, Penang, Kedah, Selangor, and Klang Valley area. The discussion revolved around the six questions mentioned above. The recorded telephone interviews transcribed for analysis. The transcriptions of each Interview questions are proceeded into traceable chunks and coded by participants' words and explanations, and issues emphasised in the literature. The data was analysed based on Clark Moustakas's (1994) 7-steps technique adapted from Van Kamm's (1966) methodology for qualitative analysis. The step followed are as follows: group and transcribe the comments from the participants manually, ii) removal of irrelevant and redundant information, iii) categorised the proceeded information into clusters and themes, iv) validate the themes v) construct a textual description based on participant's experiences, vi) create structural explanation by analysing the textual descriptions, and vii) establish the final theme for the participant's actual 
experiences. It is considered the most systematic approach to analyse the qualitative data and favoured in these studies (Hall, 2016; Creswell, 2012; Meriam et al., 2014). Below mentioned the findings and discussion.

\section{Findings and Discussion}

Table 1 shows the profile of the participants. The details depict that out of five participants from the five sandwich generation families, (D\&E) belong to the age group of 42- 45, while (A) 49 years, whereas (B\&C) belong to the age group of 52-56 years. The qualification of the participants skewed towards Masters (A \&E), whereas (B) have a PhD degree, followed by one Bachelor's degree (C), and one (D) has diploma certification. Regarding the number of children less than 18 years of age, participants (A\&D) have two children, whereas (C) three children, (B) one child, and (E) have four children less than 18 years.

Further, caregiver recipient $(\mathrm{A} \& \mathrm{C})$ have five members each, while $\mathrm{D}$ and E have 6 and 7 members, whereas, (B) have three caregiver recipients. Majority of the sandwich generation women (A, B \& E) are on full-time employment, whereas, (C) is part-time, and (D) is unemployed. The age limit of the care recipient (Elderly Parent) skewed towards 80-85 years (B, C \& E), and 70-75 years (A \& D). Majority of the sandwich generation women is taking care of their mother-in-law (A, C, D, E), whereas (B) is taking care of her father-in-law. All of the elderly parents are suffering from old age diseases such as (A) sandwich family caregiver have to deal with Alzheimer's elderly, whereas (B) is dealing with a parent who is experiencing declining of hearing ability, (C) handling parent with Arthritis and high blood pressure, (D) caring for a parent with a mentally challenged and depression, and (E) is caring for a parent with Dementia. 
Table 1.

Participant's Profile

\begin{tabular}{|c|c|c|c|c|c|}
\hline $\begin{array}{l}\text { Sandwich Generation } \\
\text { Women }\end{array}$ & $\mathbf{A}$ & B & $\mathbf{C}$ & D & $\mathbf{E}$ \\
\hline Age & 49 & 53 & 56 & 45 & 42 \\
\hline $\begin{array}{l}\text { No of children less } \\
\text { than } 18 \text { years }\end{array}$ & 2 & 1 & 3 & 2 & 4 \\
\hline $\begin{array}{l}\text { No of children above } \\
18 \text { years }\end{array}$ & 2 & 1 & 2 & 3 & 2 \\
\hline $\begin{array}{l}\text { No of children above } \\
18 \text { years of age } \\
\text { residing in home }\end{array}$ & 2 & 1 & 1 & 2 & 1 \\
\hline $\begin{array}{l}\text { Highest level of } \\
\text { Education }\end{array}$ & Masters & $\mathrm{PhD}$ & Bachelors & Diploma & Masters \\
\hline Employment & Full time & $\begin{array}{l}\text { Full } \\
\text { time }\end{array}$ & Part-time & Housewife & Full time \\
\hline $\begin{array}{l}\text { Care giver recipient } \\
\text { Age }\end{array}$ & 74 & 83 & 85 & 73 & 81 \\
\hline $\begin{array}{l}\text { Caregiver recipient } \\
\text { Relation }\end{array}$ & $\begin{array}{l}\text { Mother-in- } \\
\text { law }\end{array}$ & $\begin{array}{l}\text { Father- } \\
\text { in-law }\end{array}$ & $\begin{array}{l}\text { Mother- } \\
\text { in-law }\end{array}$ & $\begin{array}{l}\text { Mother-in- } \\
\text { law }\end{array}$ & $\begin{array}{l}\text { Mother- } \\
\text { in-law }\end{array}$ \\
\hline $\begin{array}{l}\text { Caregiver recipient } \\
\text { Health Condition }\end{array}$ & $\begin{array}{l}\text { Alzheimer's } \\
\text { Disease }\end{array}$ & $\begin{array}{l}\text { Decline } \\
\text { in } \\
\text { hearing }\end{array}$ & $\begin{array}{l}\text { Arthritis, } \\
\text { high blood } \\
\text { preassure }\end{array}$ & $\begin{array}{l}\text { Mentally } \\
\text { challenged, } \\
\text { depression }\end{array}$ & Dementia \\
\hline Total care recipient & 5 & 3 & 5 & 6 & 7 \\
\hline
\end{tabular}

Further, similarities and differences have been identified by crossreferenced one participant view with another. Crotty (1998) demonstrate that continuous comparison ends up in lesser or no themes. Table 2 illustrates the generated themes.

Thus, the overall themes developed based on the studies show the negativity of the participants' cognitive, affective, and behavioural (ABC components of an attitude) towards caregiving of elderly parents. The Attitude comprises of emotional, behavioural and cognitive components. The cognitive relates to information and knowledge and the affective on feelings (GarcíaSantillán et al., 2012). 


\section{Table 2.}

\section{Themes Generated}

\section{Interview Questions}

How do you feel about your caregiving role and a mother role?

Does your husband help you in a caregiving role?

How do you think about your family life because of the caregiving role?

Which type of challenges did you come across in your caregiving role?

What do you foresee your future and your role as sandwich generation caregiver?
Themes

No of participants

Difficult 2

Challenging 1

Struggling 1

Hectic 2

Yes 1

To some extent 1

No, a bit 1

Yes 1

Not at all 1

All time problems 1

Stilted 1

Stressful 1

Stand on toes no 2

relaxation

Financial constraints 3

Time management 3

Extreme stress 2

Less savings 3

Low morale 3

Severe health issues 4

of elderly parents

Disturb work-life 4

Emotionally disturb 2

Stress 3

Dim future 3

High alert and 2

demanding

Disturb and dark 1 


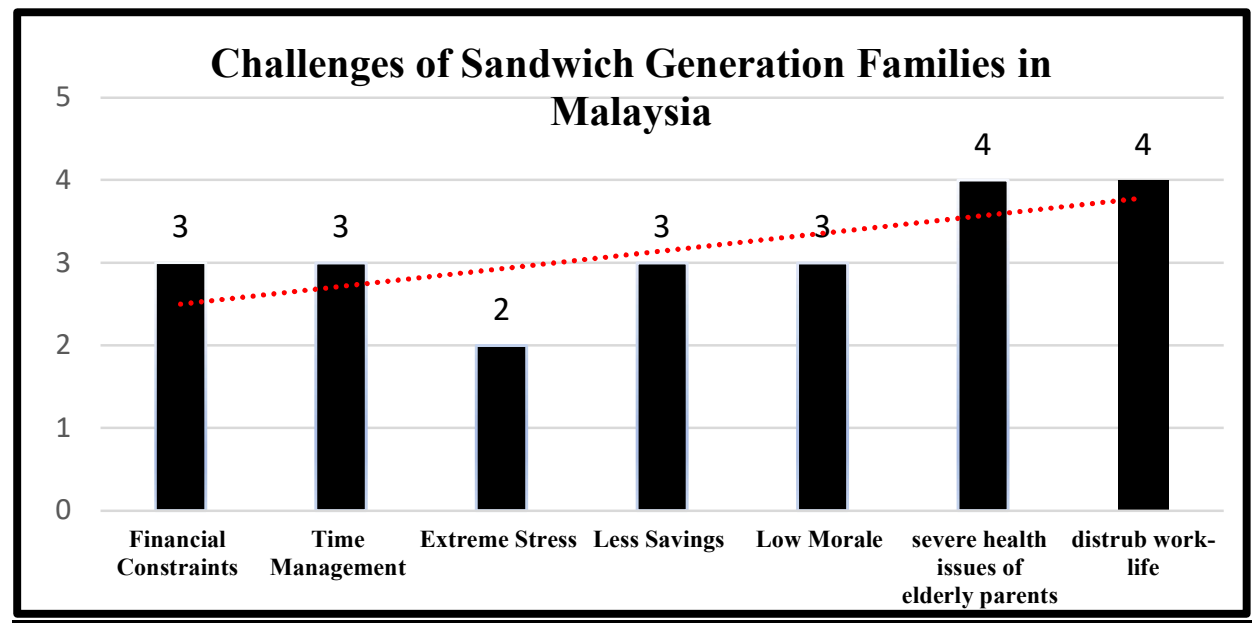

Figure la: Issues and Challenges of Sandwich Generation Families in Malaysia

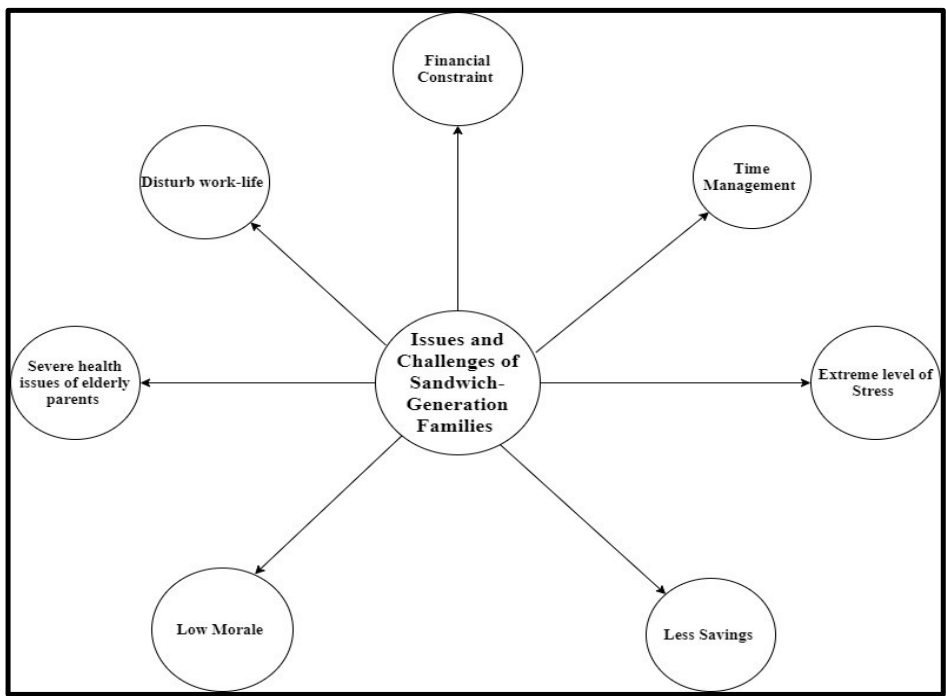

Figure 1b: Issues and Challenges of Sandwich Generation Families in Malaysia 
The Findings of the study regarding the issues and challenges of Sandwich Generation Families in Malaysia summarised in Figure 1. The majority of the respondents highlight the severity of the health condition of elderly parents and disturbing work life are the biggest challenges for them. For instance, two of the participants voiced their concern as follows:

"My Mother-in-Law is a Dementia patient, and it is challenging for me to handle her. I am a full-time employee working in the private sector. Although we have a nurse for her, still the situation for me always taut, she is not well at all and sometimes out of rage that I have to rush back to home from work as she could get settled by me only. To take care of the elderly with chronic old age diseases is very tough, and my whole family disturbed" (Participant E).

"My Mother in law is mentally challenged, and I am a housewife, I have to take care of my five children with all responsibilities of her. Yes, it is very challenging for me to handle her sometimes. We cannot afford a nurse, sometimes she behaves normally, and suddenly she becomes out of rage. I know it is God's order to take care of parents, but it is tough for me" (Participant D).

Furthermore, participants highlighted issues such as financial constraints, low morale, fewer savings, and time management. The reason being is, to look after 4 to 5 children along with the elderly parent at home with chronic diseases is challenging to manage, which ends up every month with more financial issues and no chance of any savings. Similarly, due to the hectic routine of life, the morale of sandwich generation is becoming low, and it leads to family life conflicts and works life conflicts. Hence, time management is another issue to manage the family demands along with work that collides and ends up with a conflict, which ultimately creates a tense situation. These issues mentioned below;

"I have four kids, two are less than 18 years and school going, and others are university going. My family is passing severe financial crises these days. My husband is doing both full time and part-time jobs to cover the expenses. I have to look after my children along with my mother-in-law, so 
I manage to do only one job. We try our best to save some money for our children, but we may not be able to handle it. I respect my Mother-in-law very much as being a Muslim, our religious value to take care of the elderly, but sometimes I get so stressed when I see my husband working like a machine"(Participant A).

"I try to manage many things, but most of the time; these things become very challenging for me at home and the workplace also. My morale is very down, and I feel very much stressed. Sometimes, I think I am not managing things properly" (Participant B).

"I am a part-time worker, I have five children, one of my son's lives in another state of Malaysia, and he comes on holidays only as he is studying there. Although I am a part-timer, still time management is the biggest issue as two of my kids are school going. When I go to work, my husband comes back from work, but my family life is very disturbed as an elderly parent in my house is severely ill, and we almost rushed to the hospital nearly every second day. She has severed pain cracking in her body. I try to make her feel relaxed, but her disease is out of my control now" (Participant C).

Past researches reveal that sandwich generation caregiver is experiencing a challenging role, which is demanding and time-consuming, specifically with dementia patients cared at home (Duxbury, Higgins \& Schroeder, 2011; Hammer \& Neal, 2008; McGarrigle, Cronin \& Kenny, 2013; Solberg \& Peterson, 2014; Voydanoff \& Donelly, 1999). Similarly, Solberg et al. (2014) depict that to be the caregiver of dementia patients is usually ended with adverse effects on caregivers such as in the forms of depression and anxiety feelings, as an additional treatment is required for Dementia patients by trained personnel. Hence, for most of the elderly with chronic diseases, the families are unable to handle them right, as the expertise needed with full-time attention, and time management is another constraint for the sandwich generation caregivers (Ahmad et al., 2016). In line with this, Broady (2019) explains that sandwich generation members who are taking care of children and their elder parents have a risk of physical and emotional health balance between family and job responsibilities, as well as taking care of themselves. 
Furthermore, bringing up younger children at home together with providing care for the elderly parent also increases the stress for caregivers (Tebes, 2000; Zucchella et al., 2012; Solberg et al., 2014; Ahmad et al., 2016). Below mentioned the proposed conceptual framework (Refer to Figure 2).

\section{Proposed Conceptual Framework}

Based on the literature and findings collected from the interviews, a conceptual framework is developed. The family is considered as a basic unit for the progress and development of the community in Malaysia. Thus, the familial role is a driving force for the social and economic growth (Kling, 1995; Momtaz et al., 2014) as it acts as a foundation for helping a friendly family set up (Mustaffa et al., 2013).

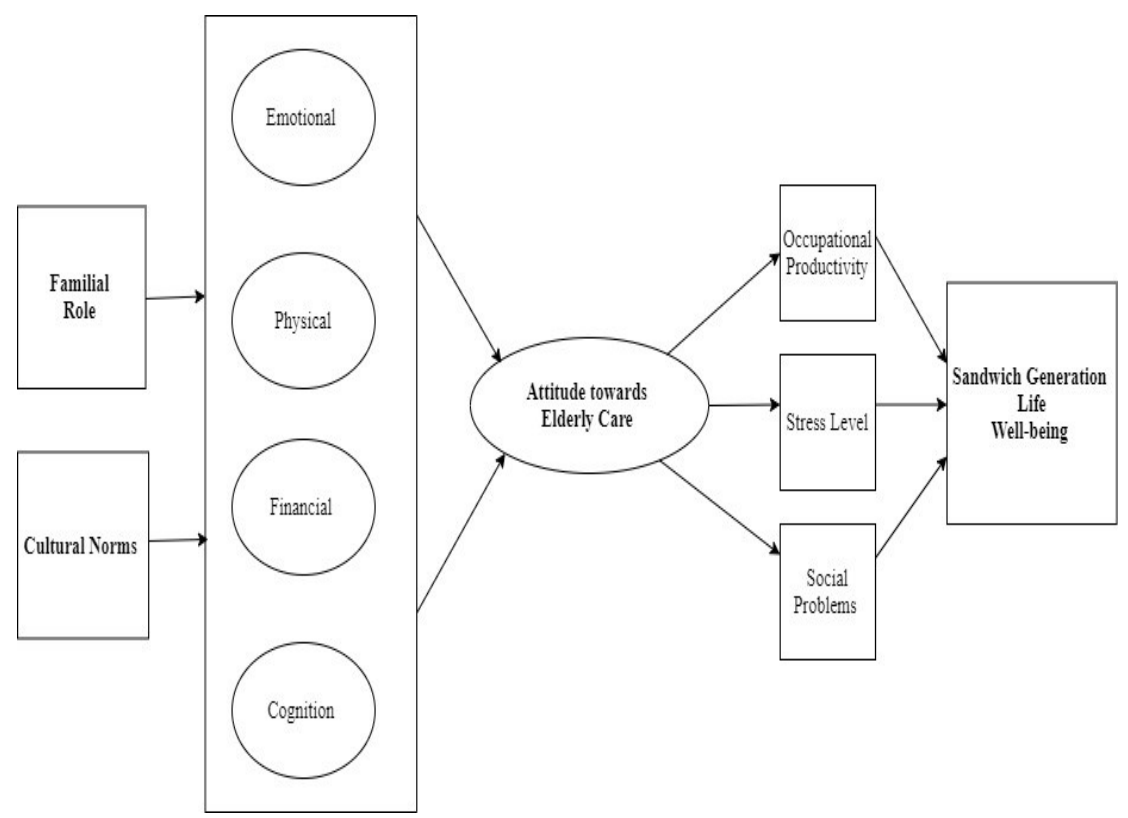

Figure 2. Conceptual Framework of Study(Noor et al., 2019)

Figure 2 depicts the effect of the familial role and cultural norms, on the emotional, physical, financial, and cognition of caregivers in the sandwich 
generation families which can result in the shaping of their attitudes towards caring of their elderly parents. The attitude influences their occupational productivity, stress level, and social problem. Consequently, negativity relates to attitudinal outcomes lead to the sandwich generation's life well-being. Therefore, the balance between household and work responsibilities are essential for family well-being (Posig et al., 2004). Furthermore, religious value, social norms, demands of family, commitments, and responsibility associated with familial roles are becoming other reasons for life conflict of a sandwich generation (Brough et al., 2002; Ford et al., 2007; Nasurdin et al., 2008).

\section{Theoretical Justification}

This study is about the issues and challenges of the Malaysian Sandwich Generation in Elderly Parents Care. The principal hypothetical theory for the support of this study is the Authentic Happiness theory. This theory highlights the three kinds of happiness, pleasure (Pleasant Life), good life (engagements), and meaningful life (Seligman, 2003). The pleasant life depicts the subjectivity, whereas, meaningful life focuses on the objective perspective and explains what is considered as most worthwhile as compared to a pleasant life. The literature proposes that the pleasant life relates to happiness in terms of raw subjective feelings with the maximum pleasure feelings and lesser pains (Bentham, 1978). Whereas, good life relates to desire of getting what do you want (Griffin, 1988; Kagan, 1998) such as happiness that lies in career accomplishment, friendship, freedom from pain, education, knowledge, etc. Therefore, Authentic Happiness theory underpins the study in terms of the full life that satisfy the criteria of a happy life (Refer to Figure $3)$. 


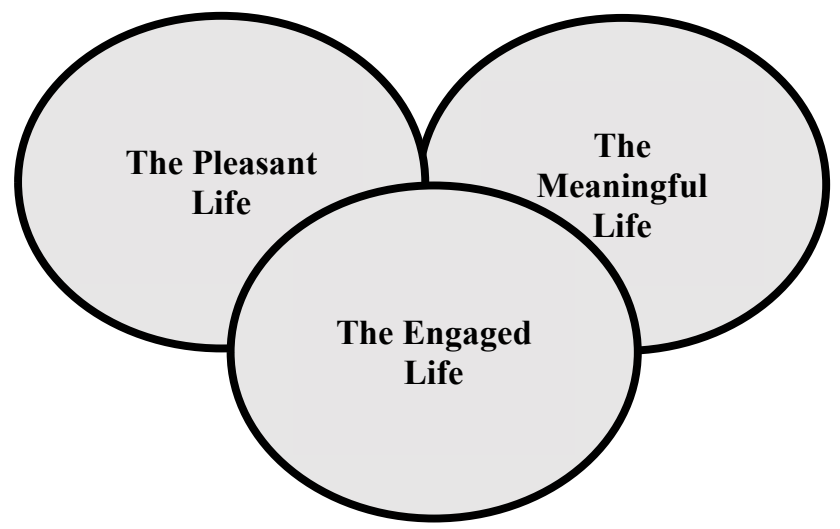

Figure 3. Authentic Happiness Theory

\section{Recommendations}

The current study postulates the main challenges confronted by the sandwich generation concerning financial, emotional, dim future, stress, fewer savings, and time management. Thus, the following three recommendations proposed to reduce the challenges of the sandwich generation.

Time Management. The workplace must provide timings for those who have the responsibility of taking care of elderly parents at home, to support the employees to deal with work-life balance. The higher authorities of the companies management can play a role by supporting the sandwich generation to cope up with time management, workload, and job stress while handling the responsibility of taking care of their elderly parents.

Besides, there should be some quota for the elderly parent care leave in the case of an emergency. The revised National Policy for Older Persons (20102015) has outlined the six strategies i.e. promotion and advocacy, lifelong learning, security and protection, management and shared responsibilities, participation, and unity across generations, research, and development), to empower the individuals, family, and community towards improving the wellbeing of older people in Malaysia. 
Stress Management. First, it is a high time to educate the community in terms of sandwich generation's huge responsibility i.e. how they are helping their elderly residing in their home in terms of care, support, and wellbeing. Thus, the sandwich generation requires acknowledgement in this regard, as their services are commendable for healthy ageing. It could help them to deal with the down feelings and dim future situation of sandwich generation caregivers. Second, support from friends, neighbours, colleagues also plays a vital role in reducing the stress among sandwich generation families (Papastavrou et al., 2012; Maon, 2016). Third, the employer also can provide a specific training program on stress management to their employees from time to time to support the employees in dealing with stress, both at work or in the home.

Financial Aid. It will be good if the government could come up with a policy in terms of fixed monthly allowance for the elderly who are getting care by their families to cut down the financial burden on the families. As in Malaysia, funding provision is for those who qualify, however, some of the elderly may not fall in the B40 category, which requires financial and health support from the government or government agencies such Ministry of Welfare and Community Development. The following recommendations proposed in this regard.

1. There is a need for proper insurance policy regarding Senior Citizen Care and Life Insurance Policy, to help the elderly in the last stages of their life and after the retirement.

2. Time Bank system should be introduced in Malaysia, as the concept is simple. In joining a time bank, people agree to take part in a system that involves earning and spending "time credits." When they spend an hour on an activity that helps others in taking care of the elderly, they will receive one-time credit. Hence, there is a need for a proper database system to record the number of hours earned by the volunteers at a young age.

3. The special edition of elderly parent care leave is required as it is missing in the policy framework just like the other leave such as maternity leave, paternity leave and annuals leave quota. 
4. The banking sector should take elderly care issues seriously and initiate funding programs in terms of elderly care irrespective of Muslims or nonMuslims category to help the ageing population.

5. There should be an allocation of special funds for senior citizens of society from the governmental side.

6. There is a need for impact management involving academicians, bankers, educational institutions to convince the governmental personal about the issues, which the elderly are facing in Malaysia.

\section{Conclusion}

The result of this study highlighted that sandwich generation family women are conceding in every situation due to the heavy burden of responsibilities in terms of household, children, and elderly parents care, along with job responsibilities. Whereas to some extent, men are overburdened due to extra jobs to cover the expenses, even then financial issues persist for sandwich generation families. Being a sandwich generation caregiver is no doubt a challenging role, which is mostly played by the women along with children care. The old-age chronic diseases are making the health condition of the elderly incurable at home, which requires expert caregivers, whereas, handling of dementia patients is becoming almost impossible at home due to patient need and lack of knowledge on the special treatment. Overall, sandwich generation families stressed due to financial issues and unable to manage the time, and at the same time facing work-family conflict and familywork conflicts. Thus, to tackle the emotional, physical, financial, and cognition problems of sandwich generation families, there is a need to create awareness on the challenges of older people care among the public, family, friends, colleagues, and neighbour. Various supports from the government, workplace, and society do play a remarkable role in helping them to lead a happy work-life balance.

Hence, gradually the sandwich generations attitudes towards elderly caregiving may transform from negativity to positivity, which will later create a positive ripple effect on society. Coupled with a strong religious foundation and socio-cultural influence, the sandwich generation of Malaysian and other neighbouring countries who hold similar value systems will be able to have meaningful life well-being as implicated by the Authentic Happiness Theory. 
In this way, a caring and loving society can develop nurtured by every individual as a part of life in the country. Since the present study conducted from the sandwich generation caregiver's perspective regarding elderly parent care that has some obvious limitations. Furthermore, studies regarding the ageing population viewpoint about health care issues can be done to get a holistic overview of elderly care issues. Therefore, future researches may conduct on the elderly perception regarding ageing care issues.

\section{References}

Ahmad, M.B., Maon, S.N.B., Mansor, M.N.M., \& Daud, N.M. (2016). Quality of life sandwich generation: A review of the literature. Proceedings of the 28th International Business Information Management Association Conference - Vision 2020: Innovation Management, Development Sustainability, and Competitive Economic Growth. pp. 4499-4504.

Bentham, J. (1978). The Principles of Morals and Legislation. Prometheus. Broady, T. (2019). The sandwich generation: Caring for oneself and others at home and at work by Ronald J. Burke and Lisa M.

Calvino. International Journal of Care and Caring, 3(2), 307309. https://doi.org/10.1332/239788219x15579336972419.

Brough, P., \& Kelling, A.(2002). Women, work, and well-being: the influence of work-family and family-work conflict. New Zealand Journal of Psychology, 31(1), 29-38.

Chassin, L., Macy, J. T., Seo, D., Presson, C. C., \& Sherman, S. J. (2010). The association between membership in the sandwich generation and health behaviors: A longitudinal study. Journal of Applied DevelopmentalPsychology, 31(1),3846.https://doi.org/10.1016/j.appdev.2009.06.001.

Creswell, J. W., \& Poth, C. N. (2012.). Qualitative inquiry \& amp; research design: choosing among five approaches. Retrieved from https://in.sagepub.com/en-in/sas/qualitative-inquiry-and-researchdesign/book246896.

Crotty, M. (1998). The foundations of social research: Meaning and perspective in the research process. SAGE. 
Duxbury, L., Higgins, C., \& Smart, R. (2011). Elder care and the impact of caregiver strain on the health of employed caregivers. Work, 40(1), 29-40. https://doi.org/10.3233/wor-2011-1204.

Ford, M. T., Heinen, B. A., \&Langkamer, K. L. (2007). Work and family satisfaction and conflict: A meta-analysis of cross-domain relations. Journal of Applied Psychology, 92(1), 5780. https://doi.org/10.1037/0021-9010.92.1.57.

García-Santillán, A., Escalera-Chávez, M., Flores-Zambada, R., F., ChongGonzález, I. S., \&López-Morales, J. S. (2012). Students, computers and mathematics: How do they interact in the teaching-learning process? (An empirical study on accounting, management and marketing undergraduate students). International Journal of Learning and Development, 2(2),178-200.https://doi.org/10.5296/ijld.v2i2.1635

Griffin, J. (1988). Well-being: Its meaning, measurement, and moral importance. Oxford University Press.

Hasson-Ohayon, I., Levy, I., Kravetz, S., Vollanski-Narkis, A., \& Roe, D. (2011). Insight into mental illness, self-stigma, and the family burden of parents of persons with a severe mental illness. Comprehensive Psychiatry, 52(1),75-

80.https://doi.org/10.1016/j.comppsych.2010.04.008

Hall, E., Chai, W., \& Albrecht, J. A. (2016). A Qualitative

Phenomenological Exploration of Teachers'Experience With

Nutrition Education. American Journal of Health Education, 47(3), 136-148. https://doi.org/10.1080/19325037.2016.1157532.

Hammer, L. B., \& Neal, M. B. (2008). Working sandwiched-generation caregivers: Prevalence, characteristics, and outcomes. The Psychologist-Manager Journal, 11(1), 93-

112.https://doi.org/10.1080/10887150801967324.

Igarashi, H., Hooker, K., Coehlo, D. P., \& Manoogian, M. M. (2013). "My nest is full:" intergenerational relationships at midlife. Journal of Aging Studies, 27(2), 102-

112. https://doi.org/10.1016/j.jaging.2012.12.004.

Kagan, S. (1998). Normative ethics. Westview Press.

Kling, Z. (1995). The Malay Family: Beliefs and Realities. Journal of

Comparative Family Studies, 26(1), 43-66.

http://www.jstor.org/stable/41602366. 
Magaña, S. M., Ramírez García, J. I., Hernández, M. G., \& Cortez, R. (2007). Psychological distress among Latino family caregivers of adults with schizophrenia: The roles of burden and stigma. Psychiatric Services, 58(3), 378-384. https://doi.org/10.1176/ps.2007.58.3.378

Maon, S. N., Mansor, M. N., Som, R. M., Ahmad, M., \&Shakri, S. A. (2016). Presenteeism among academicians at public universities in Malaysia. Advanced Science Letters, 22(5), 16061609. https://doi.org/10.1166/asl.2016.6699.

McGarrigle, C. A., Cronin, H., \& Kenny, R. A. (2013). The impact of being the intermediate caring generation and intergenerational transfers on self-reported health of women in Ireland. International Journal of Public Health, 59(2), 301-308. https://doi.org/10.1007/s00038-0130521-y.

Meriam Syed Akil, S., \& Abdullah, S. (2014). Challenges in Managing Elderly Care Centres in Malaysia. International Journal of Arts \& Sciences, 07(3), 1944-6934.

http://www.universitypublications.net/ijas/0703/html/P4RS247.xml.

Momtaz, Y., Ibrahim, R., \& Hamid, T. (2014). Cohort comparisons:

Emotional well-being among adolescents and older adults. Clinical

Interventions in Aging, 813. https://doi.org/10.2147/cia.s61636.

Moustakas, C. (1994). Phenomenological Research Methods. Google Books. https://doi.org/978-0-8039-5798-5.

Mustaffa, S., Ghanbaripanah, A., \& Ahmad, R. (2013). Assessment in family counseling. Procedia - Social and Behavioral Sciences, 93, 2205-2208. https://doi.org/10.1016/j.sbspro.2013.10.189.

Nasurdin, A. M., \& Hsia, K. L. (2008). The influence of support at work and home on work-family conflict: does gender make a difference?

Research and Practice in Human Resource Management, 16(1), 1838.https://ijbssnet.com/journals/3.pdf

Noor, S.,Isa, F.M., \& Mohd Nor, L. (2019). Ageing care centre women entrepreneur: A silver bullet for ageing tsunami in Malaysia. Sains Humanika, 12(1), 51-62. https://doi.org/10.11113/sh.v12n1.1600.

Papastavrou, E., Charalambous, A., Tsangari, H., \& Karayiannis, G. (2012).

The burdensome and depressive experience of caring. Cancer

Nursing, 35(3), 187-

194.https://doi.org/10.1097/ncc.0b013e31822cb4a0. 
Patton, M. Q. (2002). Qualitative research \& evaluation methods. SAGE. Phua, K. H., Lee, G. G., \& Yap, M.T. (2019). Ageing in Asia: contemporarytrendsandpolicyissues. World Scientific.

Pierret, C. R. (2006). The 'sandwich generation': Women caring for parents and children. Monthly Labour Review, 3-9. https://www.bls.gov/opub/mlr/2006/09/art1full.pdf.

Pines, A. M., Neal, M. B., Hammer, L. B., \&Icekson, T. (2011). Job burnout and couple burnout in dual-earner couples in the sandwiched generation. Social Psychology Quarterly, 74(4), 361-386. https://doi.org/10.1177/0190272511422452.

Posig, M., \& Kickul, J. (2004). "Work-role expectations and work family conflict: gender differences in emotional exhaustion". Women in Management Review,19(7),373-386. https://doi.org/10.1108/09649420410563430.

Robinson, M. M., Barbee, A. P., Martin, M., Singer, T. L., \&Yegidis, B. (2003). The organizational costs of caregiving. Administration in Social Work, 27(1), 83-102. https://doi.org/10.1300/j147v27n01_06. Rubin, R. M., \& White-Means, S. I. (2009). Informal caregiving: Dilemmas of sandwiched caregivers. Journal of Family and Economic Issues, 30(3), 252-267. https://doi.org/10.1007/s10834-009-9155-X.

Seligman, M. E. P. (2002). Authentic Happiness. Free Press.

Selvaratnam, D.P., Abu Bakar, N.,\& Idris, N.A.H. (2010). Economic WellBeing and Morbidity of The Elderly in Malaysia. Journal of Modern Accounting and Auditing,6(4),45-51.

Séoud, J. N., \& Ducharme, F. (2015). Factors associated with resilience among female family caregivers of a functionally or cognitively impaired aging relative in Lebanon: A correlational study. Journal of Research in Nursing, 20(7), 567-579. https://doi.org/10.1177/1744987115599672.

Sinha, M. (2013). Spotlight on Canadians: Results from the General Social Survey: Portrait of caregivers, 2012. Statistics Canada catalogue no. 89-652-X - No. 001. Ottawa, Ontario. Social and Aboriginal Statistics Division. https://www150.statcan.gc.ca/n1/en/catalogue/89-652-X.

Solberg, L. M., Solberg, L. B., \& Peterson, E. N. (2014). Caregiver stress impact scale. PsycTESTS Dataset. https://doi.org/10.1037/t37066-000. 
Tajvar, M., Arab, M. \&Montazeri, A. (2008). Determinants of health-related quality of life in elderly in Tehran, Iran. BMC Public, 8(323). http://www.biomedcentral.com/1471-2458/8/32.

Tebes, J. K., \& Irish, J. T. (2000). Promoting resilience among children of sandwiched generation caregiving women through caregiver mutual help (2014). Diverse Families, Competent Families, 153172. https://doi.org/10.4324/9781315809403-14.

Turgeman-Lupo, K., Toker, S., Ben-Avi, N., \&Shenhar-Tsarfaty, S. (2020). The depressive price of being a sandwich-generation caregiver: Can organizations and managers help? European Journal of Work and Organizational Psychology, 1-18. https://doi.org/10.1080/1359432x.2020.1762574.

Uitdehaag, M. (2019). An advance care planning conversation tool for primary health care professionals working with patients with dementia. https://doi.org/10.26226/morressier.5c76c8b3e2ea5a723761 $1 \mathrm{f} 66$.

Van Kamm, A. L. (1966). Existential foundations of psychology. Pittsburgh: Duquesne University Press.

Voydanoff, P., \& Donnelly, B. W. (1999). Multiple roles and psychological distress: The intersection of the paid worker, spouse, and parent roles with the role of the adult child. Journal of Marriage and the Family, 61(3), 725. https://doi.org/10.2307/353573.

ZehnerOurada, V. E., \& Walker, A. J. (2014). A comparison of physical health outcomes for caregiving parents and caregiving adult children. Family Relations, 63(1), 163177. https://doi.org/10.1111/fare.12046.

Zucchella, C., Bartolo, M., Pasotti, C., Chiapella, L., \&Sinforiani, E. (2012). Caregiver burden and coping in early-stage Alzheimer disease. Alzheimer Disease and Associated Disorders, 26(1), 55-60. http://dx.doi.org/10.1097/WAD.0b013e31821aa6de. 
Shaista Noor is PhD Scholar at Taylors University, Lakeside Campus Malaysia in Faculty of Business.

Filzah Md Isa is Associate Professor at Taylors University, Lakeside Campus Malaysia in Faculty of Business.

Contact Address: Faculty of Business, Taylors University, Lakeside Campus, no 1, Jalan Taylors, 47500, Subang Jaya, Selangor, Malaysia Email:shaistanoor25@gmail.com 